DOI: https://doi.org/10.32839/2304-5809/2021-11-99-89

удК 330.1

Шушкова Ю.В., Шутко А.М., Баськова Ю.С. Львівський національний університет імені Івана Франка

\title{
АНАЛІЗ СТАНУ ТА СТРУКТУРИ АКТИВІВ ВІТЧИЗНЯНИХ ПІДПРИЕМСТВ
}

\begin{abstract}
Анотація. В статті наведено економічну сутність терміну «активи», виділено основну класифікацію активів, що дає можливість оцінити характер участі усіх засобів у господарському обороті. Визначено особливості управління оборотними та необоротними активами підприемств України в умовах зовнішніх загроз, таких як спад виробництва, посилення фінансової нестабільності, пандемії коронавірусу, військових дій на сході країни тощо. Визначено основні завдання аналізу активів підприемства. Здійснено структурно-динамічний аналіз активів підприемств України за 2015-2019 роки. Доведено, що розмір, склад та структура активів підприемства зумовлюе обсяг його виробництва та рівень ефективності цього виробництва. Проаналізовано динаміку темпу зростання оборотних та необоротних активів підприемств України за 2015-2019 роки. У дослідженні розглянуто показники обсягу оборотних та необоротних активів з розподілом на великі, середні, малі та мікропідприемства за 2019 рік. Оцінено галузеву структуру активів підприемств України. Встановлено тенденції зміни обсягів оборотних та необоротних активів усіх галузей економіки України у 2018-2019 роках. Проаналізовано ефективність використання оборотних та необоротних активів за коефіціентами постійності та мобільності, а також визначено тенденції зміни співвідношення оборотних і необоротних активів підприемств України. Відзначено, що в сучасних умовах коефіціент співвідношення оборотних та необоротних активів зростає і це є позитивним явищем, оскільки підприємства України можуть швидко погашати свою заборгованість. Отримані результати дослідження можуть знайти впровадження у діяльність підприемств різних форм власності в частині здійснення заходів формування, розпорядження та управління активами.
\end{abstract}

Ключові слова: активи, оборотні активи, необоротні активи, підприемства, структура активів, коефіцієнт мобільності.

Shushkova Yuliya, Shutko Amina, Baskova Yuliia Ivan Franko Lviv National University

\section{ANALYSIS OF THE STATE AND STRUCTURE OF ASSETS OF DOMESTIC ENTERPRISES}

Summary. The article presents the economic essence of the term "assets" and highlights the basic classification of assets, which makes it possible to assess the nature of the participation of all assets in economic turnover. Peculiarities of management of current and non-current assets of Ukrainian enterprises in the conditions of external threats, such as decline in production, increasing financial instability, coronavirus pandemic, military actions in the east of the country, etc. are determined. Since the assessment of current and non-current assets of the enterprise is a complex and systematic process, so the main objectives of the analysis of enterprise assets in terms of current and non-current assets. The structural and dynamic analysis of assets of Ukrainian enterprises for 2015-2019 was performed. It is proved that the size, composition and structure of assets of the enterprise determines the volume of its production and the level of efficiency of this production. The dynamics of the growth rate of current and non-current assets of Ukrainian enterprises for 2015-2019 is analyzed. The study examines the volume of current and non-current assets divided into large, medium, small and micro enterprises in 2019. The sectoral structure of assets of Ukrainian enterprises by types of economic activity is estimated, therefore the tendencies of change of volumes of current and non-current assets of all branches of economy of Ukraine in 2018-2019 are established. The efficiency of the use of current and non-current assets by the coefficients of constancy and mobility is analyzed, as well as the tendencies of changing the ratio of current and non-current assets of Ukrainian enterprises are determined. It is noted that in modern conditions the ratio of current and non-current assets is growing and this is a positive phenomenon, as Ukrainian companies can quickly repay their debts and increase the level of business. The results of the study can be implemented in the activities of enterprises of various forms of ownership in terms of implementing measures for the formation, management and administration of assets.

Keywords: assets, current assets, non-current assets, enterprises, asset structure, mobility ratio.

Постановка проблеми. У сучасних умовах одним із провідних чинників позитивної динаміки соціально-економічного розвитку будь-якої країни світу е стабільний розвиток підприємництва. Ірунтуючись на ефрективному підприємницькому середовищі, розвиток підприемництва сприяе фрормуванню та утвердженню середнього класу, побудові громадянського суспільства, утвердженню демократії та підвищенню рівня життя громадян [1]. Таким чином, в умовах зовнішніх загроз, важливого значення у підприємницькій діяльності набуває фінансове забезпечення належного стану та структури активів підприємств.

Аналіз останніх досліджень і публікацій. Для підвищення едективності підприємницької діяльності, суб'єкти господарювання зацікавлені в відповідному стані та структурі активів. Проблема в формуванні раціональної структури активів підприемства та ощінщі результативного їх використання вимагає ретельнішого вивчення співвідношення оборотних та необоротних акти- 
вів. Вивченню дефрініції активів, дослідженню їх стану та едективності використання присвячені роботи таких учених-економістів, як: Ситник Н.С. [2], Жук О.С. [3], Козаченко Л.А. [4] та ін.

Виділення невирішених раніше частин загальної проблеми. Результати наукового дослідження можуть знайти впровадження у діяльність підприемств різних форм власності в частині здійснення заходів формування, розпорядження та управління активами, яка знаходить своє вираження через систему фінансовоекономічної індрормації.

Формулювання цілей статті. Основною метою статті є комплексне дослідження теоретичних аспектів фрункціонування оборотних та необоротних активів, практичне вивчення показників активів підприємств України та визначення особливостей управління ними.

Виклад основного матеріалу дослідження. Основою здійснення господарської діяльності кожного підприемства є активи. Відповідно до Національного положення (стандарту) бухгалтерського обліку 1 «Загальні вимоги до фрінансової звітності», активи - ресурси, контрольовані підприемством у результаті минулих подій, викорис- тання яких, як очікуеться, приведе до надходження економічних вигод у майбутньому [5]. То ж до активів відносяться всі види майна підприемства, що належить йому на правах власності і використовуються для здійснення статутної діяльності. Саме розуміння активів як джерела отримання грошових потоків $є$ основою політики управління активами будь-якого підприємства [4].

Кожне підприемство фрормуе власну політику управління активами. Ця політика встановлюе необхідну потребу в активах, визначає їх склад, структуру, джерела фінансування, враховуючи специфіку діяльності підприемства та вплив фракторів зовнішнього та внутрішнього середовища.

Управляючи своїми активами підприемство визначає необхідність попередньої їхньої класифрікації, зокрема за характером участі у господарському процесі та швидкості обороту на оборотні та необоротні активи [2, с. 501]. На рис. 1 зображено склад активів підприемства.

Також в процесі управління активами підприємства важливу роль відіграє співвідношення між оборотними та необоротними активами. З одного боку, нестача оборотних активів призводить до періодичних збоїв у роботі підприемства,

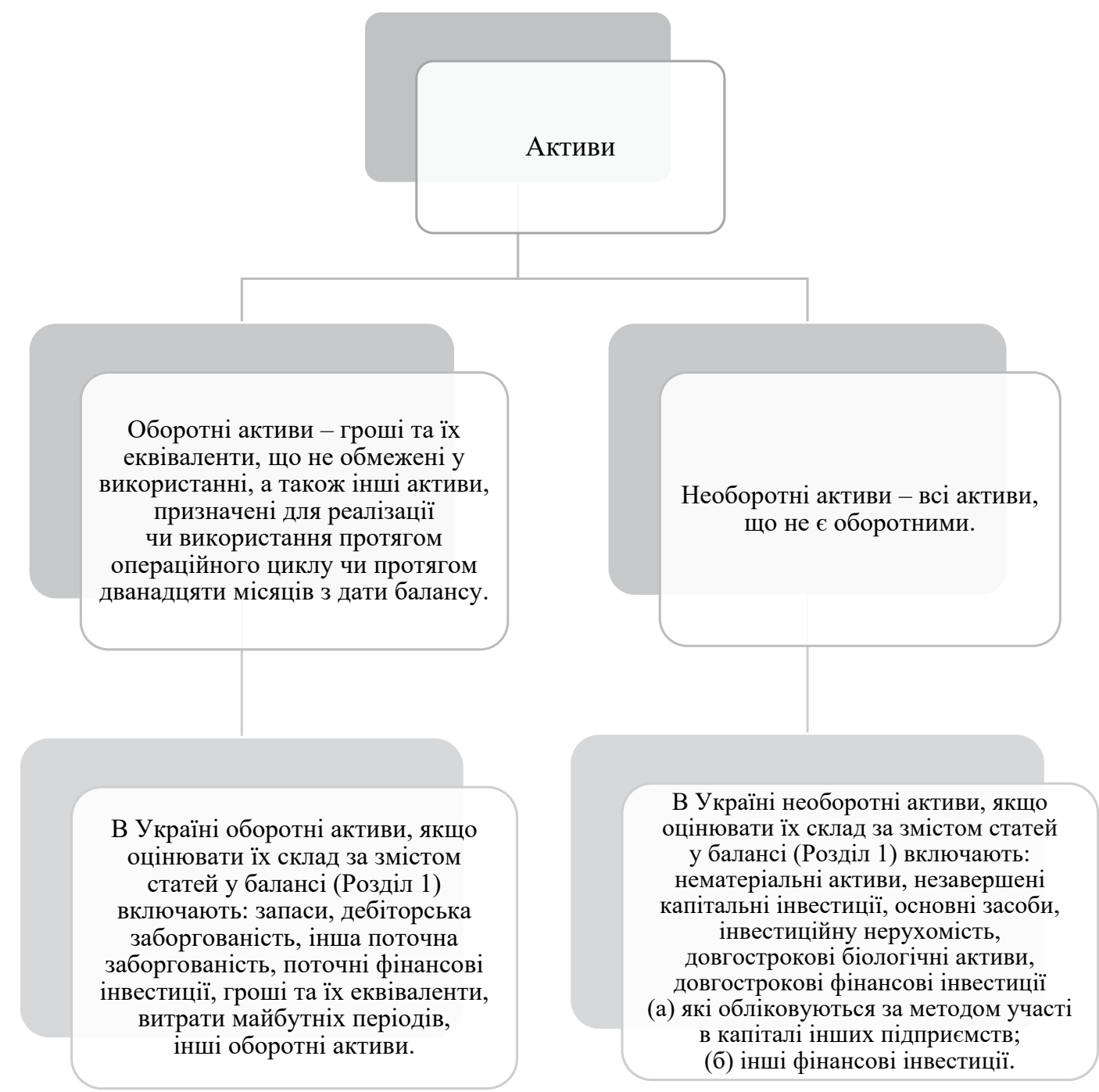

Рис. 1. Класифікація активів підприемства відповідно до Національного положення бухгалтерського обліку 1 «Загальні вимоги до фінансової звітності» 


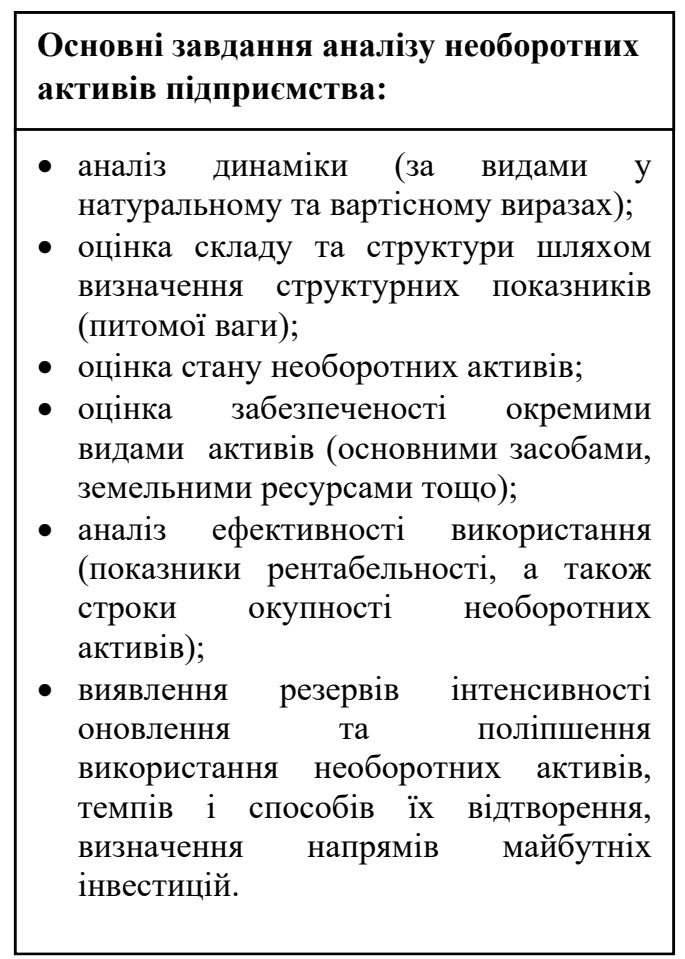

Основні завдання аналізу оборотних активів підприсмства:

- аналіз динаміки за видами активів та в цілому;

- аналіз складу та структури (питома вага);

- розрахунок коефіцієнтів - відношень між окремими видами активів та джерелами їх формування;

- оцінка забезпеченості окремими видами ресурсів (виробничими запасами, грошовими коштами тощо) та планування потреби в оборотному капіталі;

- аналіз оборотності за показниками, шо дають оцінку ефективності використання оборотного капіталу та його елементів за фактором часу;

- аналіз ефективності використання, який передбачає визначення показників рентабельності капіталу підприємства та його складових.

Рис. 2. Основні завдання аналізу активів підприемства

зниження ліквідності та зниження його фрінансової стабільності, 3 іншого, нестача необоротних - до невиконання запланованих обсягів виробництва, недостатності обладнання та робочих приміщень i, в результаті, до зниження ринкової вартості підприемства. Поряд із цим, надмірний обсяг оборотних активів зумовлюе наявність у підприемства тимчасово вільних, недіючих активів, надлишкові витрати фрінансування, в результаті - зниження прибутку підприємства; а надмірний обсяг необоротних - до погіршення рівня їх корисного використання та зниження вартості підприємства [6, с. 248].

Тому аналіз та ощінка оборотних та необоротних активів підприемства є комплексним процесом, який передбачає досягнення ряду завдань (рис. 2).

Дослідимо динаміку, структуру та склад активів вітчизняних підприемств за період 2015-2019 рр. (табл. 1).

Аналізуючи дані табл. 1, зауважимо, що протягом останніх років спостерігаеться зростання як оборотних, так і необоротних активів підприємств. При цьому питома вага необоротних активів коливається від 49,2\% у 2015 році до 42,3\% у 2019 році, що пов'язано з збільшенням обсягів частки оборотних активів у сукупному балансі підприемств за аналізований період (від 50,8\% у 2015 році до $57,7 \%$ у 2019 році).

За аналізований період спостерігається стрімке зростання необоротних активів на 889512,4 млн. грн., або у 1,22 рази. Станом на 31.12 .2019 обсяг оборотних активів підприемств України становив 6640282,3 млн. грн., що на 2531679,7 млн. грн. більше, ніж у 2015 р.

Для аналізу сучасного стану активів підприємств розглянемо динаміку темпу зростання оборотних та необоротних активів підприемств України за 2015-2019 рр., яка розрахована на основі даних табл. 1 (рис. 3).

Варто відмітити, що протягом останніх років динаміка темпу зростання оборотних та необоротних активів має цікаву траєкторію. Так, у 2017 році оборотні активи зменшились на $2,11 \%$ (або на 121999,1 млн. грн.), проте в наступні роки вони почали поступово зростати і станом на 31.12.2019 темп зростання оборотних активів становить 5,65\%.

При цьому, згідно даних Державної служби статистики України, у 2019 рощі середні підприємства акумулювали $36,76 \%$ від зального обсягу оборотних активів (2441073,5 млн. грн.), великі підприемства - 30,53\% (2027717,4 млн. грн.), мікро підприемства - 18,13\% (1203431,6 млн. грн.), а малі підприємства в своєму розпорядженню

Структурно-динамічний аналіз активів підприемств України за 2015-2019 роки

\begin{tabular}{|l|c|c|c|c|c|c|c|c|c|c|}
\hline & \multicolumn{2}{|c|}{$\mathbf{2 0 1 5}$} & \multicolumn{2}{c|}{$\mathbf{2 0 1 6}$} & \multicolumn{2}{c|}{$\mathbf{2 0 1 7}$} & \multicolumn{2}{c|}{$\mathbf{2 0 1 8}$} & \multicolumn{2}{|c|}{$\mathbf{2 0 1 9}$} \\
\cline { 2 - 11 } & млн. грн. & \% & $\begin{array}{c}\text { млн. } \\
\text { грн. }\end{array}$ & $\mathbf{\%}$ & млн. грн. & \% & млн. грн. & \% & млн. грн. & \% \\
\hline Необоротні активи & 3965180,7 & 49,2 & 4218974,7 & 42,3 & 4310961,6 & 43,3 & 4592984,1 & 42,3 & 4854693,1 & 42,3 \\
\hline Оборотні активи & 4108602,6 & 50,8 & 5772816,5 & 57,7 & 5650817,4 & 56,7 & 6285066,5 & 57,7 & 6640282,3 & 57,7 \\
\hline Баланс & 8073783,3 & 100 & 9991791,2 & 100 & 9961779,0 & 100 & 10878050,6 & 100 & 11494975,4 & 100 \\
\hline
\end{tabular}




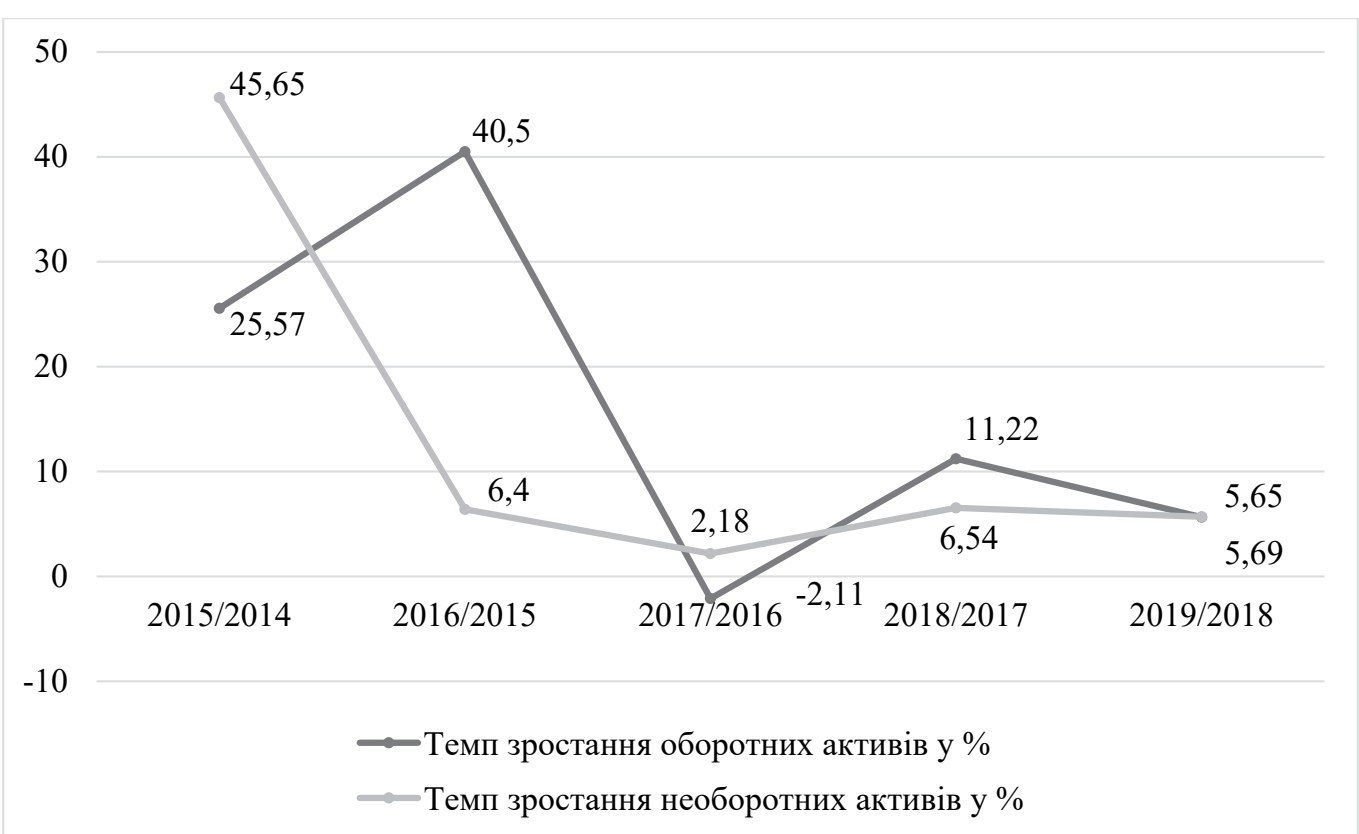

Рис. 3. Динаміка темпу зростання оборотних та необоротних активів підприемств України за 2015-2019 pp., \%

Джерело: розроблено авторами за даними [8]

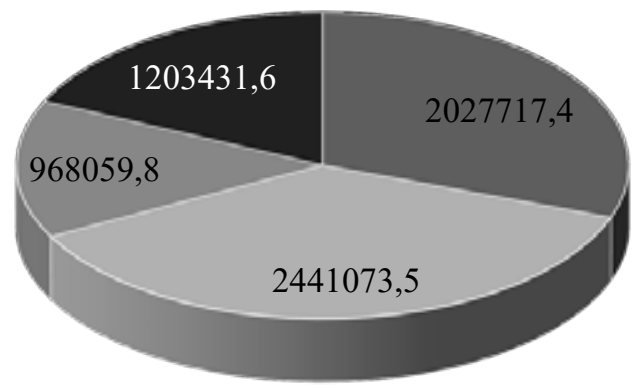

- Обсяг оборотних активів великих підприємств, млн. грн

- Обсяг оборотних активів середніх підприємств, млн. грн

- Обсяг оборотних активів малих підприємств, млн. грн

- Обсяг оборотних активів мікро підприємств, млн. грн

Рис. 4. Обсяг оборотних активів з розподілом на великі, середні, малі та мікропідприемства станом на 31.12.2019, млн. грн.

Джерело: розроблено авторами за даними [8]

мають лише 14,58\% (968059,8 млн. грн.) оборотних активів (рис. 4).

Станом на 2019 р. найбільшу частку у структурі оборотних активів займала дебіторська заборгованість - 4072113 млн. грн., або 61,3\%, на другому місці є запаси підприемств в обсязі 1624162 млн. грн., або 24,5\%, а третє місце належить грошовим коштам, які становлять 463514,8 млн. грн (6,98\%).

Щодо необоротних активів, то станом на 31.12.2019 найбільше їх скупчено у великих підприемств, а саме 2429292,3 млн. грн. (50,04\% від загального обсягу необоротних активів підприємств України). Друге місце за обсягом необоротних активів належить середнім підприемствам (1339427,1 млн. грн., або 27,59\%). Мікро підпри- ємства акумулюють 578407,6 млн. грн. (11,91\%), а малі - 507565,9 млн. грн. (10,46\%) (рис. 5).

Найбільшу часту в структурі необоротних активів у 2019 р. займали основні засоби та нематеріальні активи - 3271397 млн. грн. (67,5\%). На довгострокові фрінансові інвестищії припадае 755972,2 млн. грн, або 15,6\%, а на незавершені капітальні інвестиції - всього 487222,9 млн. грн., або 10\%.

Для більш поглибленого аналізу сучасного стану активів підприемств України розглянемо їх склад за видами економічної діяльності у 2018-2019 рр. (табл. 2).

Згідно даних табл. 2, обсяги необоротних активів, які використовуються підприемствами у різних галузях економіки України, показують позитив- 


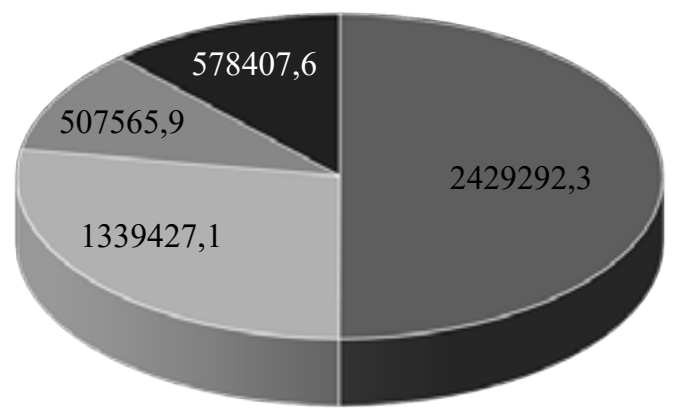

- Обсяг необоротних активів великих підприємств, млн. грн

- Обсяг необоротних активів середніх підприємств, млн. грн

- Обсяг необоротних активів малих підприємств, млн. грн

- Обсяг необоротних активів мікро підприємств, млн. грн

Рис. 5. Обсяг необоротних активів з розподілом на великі, середні, малі та мікропідприемства станом на 31.12 .2019 , млн. грн.

Джерело: розроблено авторами за даними [8]

ну тенденцію. Варто зауважити, що такі активи на 2019 р. становлять 4854693 млн. грн., що на 261709 млн. грн. більше, ніж 2018 р. Найбільші обсяги необоротних активів використовуються в промисловості (1755294,9 млн. грн.), транспортній сфрері, складському господарстві, поштовій та кур'єрській діяльності (678100,1 млн. грн).

Обсяги оборотних активів також зросли (на 355215,8 млн.) і у 2019 році дорівнювали 6640282,4 млн. грн. Вагома частка оборотних активів припадає та такі сфери діяльності українських підприемств як: оптова та роздрібна торгівля, ремонт автотранспортних засобів і мотоциклів (2149443,6 млн. грн.), промисловість (1883722,4 млн. грн.) та сільське, лісове та рибне господарство (640995, 1 млн. грн.).

Водночас обсяги активів соціальної сдери (освіта, охорона здоров'я, мистецтво, спорт, розваги та відпочинок, соціальні послуги) знаходяться на досить низькому рівні.

Оцінку структури активів підприемств проведемо на основі коедіцієнтів постійності, мобільності та співвідношення оборотних і необоротних активів підприемств України (табл. 3).

Структура активів підприемств України за видами економічної діяльності

Таблиця 2 у 2018-2019 рр., млн. грн.

\begin{tabular}{|c|c|c|c|c|}
\hline \multirow{3}{*}{ Види економічної діяльності } & \multicolumn{4}{|c|}{ Активи } \\
\hline & \multicolumn{2}{|c|}{ необоротні активи } & \multicolumn{2}{|c|}{ оборотні активи } \\
\hline & 2018 & 2019 & 2018 & 2019 \\
\hline Усього & 4592984 & 4854693 & 6285066,6 & 6640282,4 \\
\hline сільське, лісове та рибне господарство & 329412,9 & 389371,6 & 654180,7 & 640995,1 \\
\hline промисловість & 1517422,4 & 1755294,9 & 1914514,4 & 1883722,4 \\
\hline будівництво & 135397,7 & 146930,8 & 328063,3 & 394884,6 \\
\hline $\begin{array}{l}\text { оптова та роздрібна торгівля; ремонт } \\
\text { автотранспортних засобів і мотоциклів }\end{array}$ & 299895,4 & 348879,1 & 2013853,7 & 2149443,6 \\
\hline $\begin{array}{l}\text { транспорт, складське господарство, } \\
\text { поштова та кур'єрська діяльність }\end{array}$ & 765623,6 & 678100,1 & 262213,0 & 252287,6 \\
\hline тимчасове розміщування й організація харчування & 29550,2 & 30469,3 & 16533,7 & 18209,7 \\
\hline інформація та телекомунікації & 99175,2 & 120646,8 & 72594,4 & 70912,9 \\
\hline фінансова та страхова діяльність & 159014,7 & 154272,4 & 256699,5 & 321796,6 \\
\hline операції з нерухомим майном & 388852,8 & 417236,6 & 310284,6 & 333618,5 \\
\hline професійна, наукова та технічна діяльність & 528944,9 & 470209,6 & 343020,5 & 435779,6 \\
\hline $\begin{array}{l}\text { діяльність у сфері адміністративного та } \\
\text { допоміжного обслуговування }\end{array}$ & 282432,6 & 247568,7 & 88759,9 & 108250,8 \\
\hline освіта & 2797,5 & 3607,3 & 1548,4 & 2399,6 \\
\hline охорона здоров'я та надання соціальної допомоги & 18559,2 & 50805,7 & 8377,5 & 15819,6 \\
\hline мистецтво, спорт, розваги та відпочинок & 29326,1 & 34327,0 & 11207,6 & 8250,9 \\
\hline надання інших видів послуг & 6578,8 & 6973,1 & 3215,4 & 3910,9 \\
\hline
\end{tabular}

Джерело: розроблено авторали за данили [8] 
Динаміка показників структури активів за 2015-2019 рр.

\begin{tabular}{|l|c|c|c|c|c|}
\hline \multicolumn{1}{|c|}{ Показники } & $\mathbf{2 0 1 5}$ & $\mathbf{2 0 1 6}$ & $\mathbf{2 0 1 7}$ & $\mathbf{2 0 1 8}$ & $\mathbf{2 0 1 9}$ \\
\hline $\begin{array}{l}\text { Коефіціент постійності } \\
\text { (Необоротні активи / Баланс) }\end{array}$ & 0,49 & 0,42 & 0,42 & 0,42 & 0,42 \\
\hline $\begin{array}{l}\text { Коефіціент мобільності } \\
\text { (Оборотні активи / Баланс) }\end{array}$ & 0,51 & 0,58 & 0,57 & 0,58 & 0,58 \\
\hline $\begin{array}{l}\text { Коефіціент співвідношення } \\
\text { оборотних і необоротних активів }\end{array}$ & 1,04 & 1,37 & 1,31 & 1,37 & 1,37 \\
\hline
\end{tabular}

Джерело: розроблено авторами за даними [8]

За даними табл. 3, можна спостерігати, що коефіцієнт постійності має негативну тенденцію, оскільки він зменшився у 2016 році на 0.07 од., порівняно з 2015 роком. Це свідчить про спад виробничого потенціалу підприємств України. Впродовж 2016-2019 років даний показник є незмінним і становить 0,42 од., що вказує на частку необоротних активів у майні підприемств. Оберненим показником $є$ коедіціент мобільності, який показує, що майно підприемства може змінити структуру протягом короткого періоду часу. Даний показник зріс на 0,07 од. і становить 0,58 у 2019 році.

Важливим індикатором едрективності активів підприемства $є$ коефіціент співвідношення оборотних та необоротних активів, який свідчить про ліквідність балансу. За аналізований період даний показник зростає і це є позитивним явищем, оскільки підприемства України можуть швидко погашати свою заборгованість.

Отже, аналіз та оцінка стану активів підприємств є комплексним процесом, оскільки під час їхнього здійснення необхідно оцінити майновий стан підприемства, дослідити динаміку оборотних та необоротних активів, їхні темпи приросту, тощо. Вмілі аналіз, використання та управління оборотними і необоротними активами здатні покращити фінансовий стан будь-якого підприемства.

Позитивним явищем використання активів підприемств являються зміни в їхній структурі у сторону збільшення питомої ваги оборотних активів. Як видно з таблиць 1 та 3 , підприемства України ефрективно управляють своїми активами. Станом на 2019 рік частка оборотних активів становить 57,7\%, що свідчить про:

- ліквідність балансу, тобто підприємства України можуть швидко погашати свою заборгованість;

- прискорення оборотності засобів виробництва;

- підвищення рівня ділової активності і едективне використання оборотних ресурсів.

Висновки 3 даного дослідження i перспективи. В сучасних реаліях на базі вітчизняного досвіду одним із чинників підвищення ефрективності підприемницької діяльності є оцінка стану оборотних та необоротних активів підприемства. Активи підприемства - це засоби суб'єкта господарювання, які потрібні для його функціонування у різних формах діяльності 3 метою одержання майбутніх вигод. Розмір, склад та структура активів підприемства зумовлюе обсяг його виробництва та рівень ефективності цього виробництва. Результати аналізу активів підприемств України за 2015-2019 роки свідчать, що незважаючи на зменшення питомої ваги необоротних активів у сукупному балансі підприемств, вони продовжують зростати. В свою чергу, оборотні активи також мають тенденщію до зростання.

\section{Список літератури:}

1. Мельник M.I. Формування бізнес-середовища України в умовах інституційних трансформацій : монографрія. Львів : Вид-во ІРД НАН України, 2012. 568 с.

2. Фінансовий менеджмент : навчальний посібник / [Ситник Н.С., Стасишин А.В., Гукалюк А.Ф., Західна О.Р., Сич О.А., Шушкова Ю.В.] ; за заг. ред. Н. С. Ситник. Львів : ЛНУ імені Івана Франка, 2020. 845 с.

3. Жук О.С. Оцінка стану та структури активів підприемства. Наукові записки Національного університету "Острозька академія". Серія "Еконоліка» : науковий журнал. Острог : Вид-во НУ«ОА», грудень 2016. № 3(31). C. 16-20. URL: https://ecj.oa.edu.ua/articles/2017/31/5.pdf (дата звернення: 15.10.2021).

4. Козаченко Л.А., Жакоті А.Б. Активи підприємства як об’єкт фрінансового управління. Миколайвський міжрегіональний інститут розвитку людини ВНЗ «Університет Украӥна». URL: http://www.rusnauka.com/ 1_NIO_2013/Economics/10_124520.doc.htm (дата звернення: 15.10.2021).

5. Національне положення (стандарт) бухгалтерського обліку 1 «Загальні вимоги до фінансової звітності» : наказ Міністерства фінансів України від. 07.02.2013 p. № 73. URL: https://zakon.rada.gov.ua/laws/show/z033613\#Tеxt (дата звернення: 15.10.2021).

6. Смирнова Н.В. Аналіз співвідношення оборотних і необоротних активів сільськогосподарських підприємств. Еконолічний аналіз : зб. наук. праць. Тернопіль : Видавничо-поліграфічний центр Тернопільського національного економічного університету “Економічна думка”, 2014. Том 18. № 2. С. 246-252.

7. Єгорова О.В., Дорогань-Писаренко Л.О., Тютюнник Ю.М. Економічний аналіз : навч. посіб. Полтава : РВВД ПДАА, 2018. 290 c.

8. Державна служба статистики України. Офіційний сайт. URL: http://www.ukrstat.gov.ua/ (дата звернення: 17.10.2021).

\section{References:}

1. Melnyk M.I. (2012) Formuvannia biznes-seredovyshcha Ukrainy v umovakh instytutsiinykh transformatsii [Formation of the business environment of Ukraine in the conditions of institutional transformations]. Lviv: IRD NAN of Ukraine. (in Ukrainian)

2. Sytnyk N.S., Stasyshyn A.V., Gukalyuk A.F., Zapadna O.R., Sych O.A., Shushkova Y.V. (2020) Finansovyy menedzhment [Financial management]. (in Ukrainian) 
3. Zhuk O.S. (2016) Otsinka stanu ta struktury aktyviv pidpryiemstva [Assessment of the state and structure of enterprise assets]. Scientific notes of the National University "Ostroh Academy", no. 3(31), pp. 16-20. Available at: https://ecj.oa.edu.ua/articles/2017/31/5.pdf (accessed 15 October 2021).

4. Kozachenko L.A., Zhakoti A.B. Aktyvy pidpryiemstva yak obiekt finansovoho upravlinnia [Assets of the enterprise as an object of financial management]. Mykolaivskyi mizhrehionalnyi instytut rozvytku liudyny VNZ « Universytet Ukraina" [Mykolayiv Interregional Institute of Human Development, University of Ukraine]. Available at: http://www.rusnauka.com/1_NIO_2013/Economics/10_124520.doc.htm (accessed 15 October 2021).

5. Ministerstvo finansiv Ukrainy (2013) Natsionalne polozhennia (standart) bukhhalterskoho obliku 1 «Zahalni vymohy do finansovoi zvitnosti» [National Regulation (Standard) of Accounting 1 "General requirements for financial reporting»"]. Available at: https://zakon.rada.gov.ua/laws/show/z0336-13\#Text (accessed 15 October 2021).

6. Smyrnova N.V. (2014) Analiz spivvidnoshennia oborotnykh i neoborotnykh aktyviv silskohospodarskykh pidpryiemstv [Analysis of the ratio of current and non-current assets of agricultural enterprises]. Ekonomichnyi analiz, no. 18(2), pp. 246-252. (in Ukrainian)

7. Egorova O.V., Dorogan-Pisarenko L.O., Tyutyunnik Y.M. (2018) Ekonomichnyi analiz [Economic analysis]. Poltava: RVVD PDAA. (in Ukrainian)

8. State Statistics Service of Ukraine. Official site. Available at: http://www.ukrstat.gov.ua/ (accessed 17 October 2021). 